Research Paper

\title{
Long Term Persistence of IgE Anti-Influenza Virus Antibodies in Pediatric and Adult Serum Post Vaccination with Influenza Virus Vaccine
}

\author{
Tamar A. Smith-Norowitz ${ }^{1,5}{ }^{凶}$, Darrin Wong², Melanie Kusonruksa², Kevin B. Norowitz ${ }^{1,5}$, Rauno Joks ${ }^{3,5}$, \\ Helen G. Durkin 2,5 , Martin H. Bluth4
}

1. Departments of Pediatrics, S.U.N.Y. Downstate Medical Center, Brooklyn, New York 11203, USA

2. Departments of Pathology, S.U.N.Y. Downstate Medical Center, Brooklyn, New York 11203, USA

3. Departments of Medicine, S.U.N.Y. Downstate Medical Center, Brooklyn, New York 11203, USA

4. Department of Pathology, Wayne State University School of Medicine, Detroit, Michigan, 48201, USA

5. Center for Allergy and Asthma Research, S.U.N.Y. Downstate Medical Center, Brooklyn, New York 11203, USA

Corresponding author: Tamar A. Smith-Norowitz, Ph.D., SUNY Downstate Medical Ctr., Dept of Pediatrics, Box 49,450 Clarkson Ave., Brooklyn, New York 11203, (718) 270-1295, (718) 270-3289 (fax), tamar.smith-norowitz@downstate.edu

(C) Ivyspring International Publisher. This is an open-access article distributed under the terms of the Creative Commons License (http://creativecommons.org/ licenses/by-nc-nd/3.0/). Reproduction is permitted for personal, noncommercial use, provided that the article is in whole, unmodified, and properly cited.

Received: 2010.12.22; Accepted: 2011.02.07; Published: 2011.03.18

\begin{abstract}
The production of IgE specific to different viruses (HIV-I, Parvovirus BI9, Parainfluenza virus, Varicella Zoster Virus), and the ability of IgE anti-HIV-I to suppress HIV-I production in vitro, strongly suggest an important role for IgE and/or anti viral specific lgE in viral pathogenesis. Nevertheless, the presence and persistence of $\lg E$ anti-Influenza virus antibodies has not been studied. Total serum IgE and specific lgE and IgG anti-Influenza virus antibodies were studied in children $(\mathrm{N}=3)(\mathrm{m} / \mathrm{f} \mathrm{I} 4-16$ y/o $)$ and adults $(\mathrm{N}=3)(\mathrm{m} / \mathrm{f}, 4 \mathrm{I}-49$ y/o) 2-20 months after vaccination with Influenza virus (Flumist ${ }^{\circledR}$ or Fluzone ${ }^{\circledR}$ ), as well as in non-vaccinated children $(\mathrm{N}=2)$. (UniCAP total IgE Fluoroenzymeimmunoassay, ELISA, Immunoblot). We found that serum of vaccinated children and adults contained IgE and IgG anti-Influenza virus antibodies approaching two years post vaccination. Non-vaccinated children did not make either lgE or IgG anti-Influenza antibodies. Similar levels of IL-2, IFN-y, IL-4, and IL-10 cytokines were detected in serum of vaccinated compared with non vaccinated subjects $(p>0.05)$, as well as between vaccinated adults compared with vaccinated children and non vaccinated subjects $(p>0.05)$. Vaccinated children and adults continue to produce IgE anti-Influenza virus antibodies long term post vaccination. The long term production of IgE anti-Influenza virus antibodies induced by vaccination may contribute to protective immunity against Influenza.
\end{abstract}

Key words: IgE, Influenza virus, Influenza virus vaccine

\section{INTRODUCTION}

Previous studies in our laboratory have investigated the role of $\operatorname{IgE}$ and the immune response to specific viruses including: Parvovirus B19 in children [1], HIV-1 in HIV-1 seropositive, non progressor pediatric patients [2, 3], Varicella Zoster Virus (VZV) [4, $5]$, as well as in both children and adults with a past history of chicken pox infection or VZV vaccination [6]. Other studies in our laboratory also identified IgE anti- spirochete antibodies (B. Burgdorferi) and its persistence one year later in serum of lyme-infected children [7].

Studies in humans and animals reported by others have identified IgE anti-virus antibodies in several viral infections including respiratory syncytial virus (RSV) [8, 9], parainfluenza [10], HTLV-1 [11], Puumala virus [12], HSV-1, HSV-2, and Epstein-Barr 
virus [13], and blue tongue virus in cattle [14].

Studies of Grunewald, et al., reported Influenza A virus-specific IgE antibodies in the serum of infected mice, and showed local anaphylaxis after rechallenge with the Influenza A virus antigen; these mice developed virus-specific mast cell degranulation in the skin [15]. Recent studies of Davidsson, et al demonstrated in healthy human subjects, with no known allergy, IgE responses against Influenza A [16]. No anaphylactic reactions were associated with vaccination [16]. However, serum $\operatorname{IgE}$ levels were increased after Influenza vaccination, which might indicate a participation of $\operatorname{IgE}$ in viral defense [16]. Earlier studies of Dobber, et al also found that IgE specific Influenza virus antibodies were increased after influenza vaccination in mice [17]. Interestingly, low levels of total Influenza virus-specific antibody secreting cells (ASCs) have been reported in blood, tonsils, and nasal mucosa of non-allergic study subjects that had not been recently vaccinated or naturally infected with Influenza virus [18]. In their earlier studies, they found that Influenza virus-specific antibodies in the oral fluid (saliva) consist mainly of secretory $\operatorname{Ig} \mathrm{A}(\operatorname{sig} \mathrm{A})[19]$.

This study is the first, to our knowledge, to describe the long term persistence of IgE anti-Influenza virus antibodies in serum of IgE positive and negative vaccinated pediatric and adult subjects, approaching two years post vaccination. The exact role of $\operatorname{IgE}$ in Influenza virus infection remains to be elucidated; however, the presence of IgE anti Influenza virus antibodies several months post vaccination warrants further investigation of the biological significance, if any, of these antibodies.

\section{MATERIALS AND METHODS}

\section{Patient specimen description}

Peripheral blood ( $3 \mathrm{ml}$ total) was obtained from both pediatric $(\mathrm{N}=3)(\mathrm{m} / \mathrm{f}, 14-16$ yrs old $)$ and adult $(\mathrm{N}=3)(\mathrm{m} / \mathrm{f}, 41-49$ yrs old) Caucasian subjects from the SUNY Downstate Allergy Clinic, who were both atopic and non atopic, with normal $(<100 \mathrm{IU} / \mathrm{mL})$ or elevated serum IgE levels. Atopic subjects were skin prick positive $(\mathrm{N}=2)$ for environmental (e.g. mixed tree and grass, ragweed, weeds, and dust mite) or food allergens. Exclusion criteria included food allergy to egg and antibiotics. At the time of study, the subjects had not received allergy therapy, and were not being treated with any medication. Subjects did not have a past history of parasite infection. Approval was obtained from the SUNY Downstate Institutional Review Board, and the procedures followed were in accordance with institutional guidelines involving human subjects.

\section{Vaccine description}

All adults were vaccinated with Influenza Virus Vaccine Fluzone ${ }^{\circledR}$ (inactivated Influenza Virus Vaccine, 2009-2010 Formula; Sanofi Pasteur Inc., Swiftwater, PA) and children were vaccinated with Flumist ${ }^{\circledR}$ (live attenuated Influenza Virus Vaccine, Intranasal, 2009-2010 Formula; MedImmune,LLC, Gaithersburg, MD). Each $0.25 \mathrm{~mL}$ dose of Fluzone vaccine contains $7.5 \mathrm{mcg}$ of influenza virus hemagglutinin (HA) and each $0.5 \mathrm{~mL}$ dose contains $15 \mathrm{mcg}$ HA from each of the following 3 viruses: A/Brisbane/59/2007, IVR-148 (H1N1), A/Uruguay/716/2007/, NYMC X-175C (H3N2) (an A/Brisbane/10/2007-like virus), and B/Brisbane/60 /2008. Each $0.2 \mathrm{~mL}$ dose of Flumist intranasal spray contains 10 FFU (fluorescent focus units) of live attenuated influenza virus reassortants of each of the three strains for the 2009-2010 season: A/California/7/2009 (H1N1), A/Perth/16/2009 (H3N2), and B/Brisbane/60/2008.

Time post vaccination for subjects was 2-20 months. Past history of vaccination was confirmed by positive immunoblot for IgG anti Influenza virus. (See methods below.)

\section{Total serum IgE}

Blood was collected and immunoglobulin (Ig) levels (IgE) were detected in serum (Quest Diagnostics, Inc. Teterboro, NJ), which was performed according to manufacturer's recommendation. Reference range for healthy adult or child serum: IgE: 20-100 IU/mL.

\section{Influenza virus serum antibody detection: Im- munoblot}

The presence of IgE or IgG anti-Influenza antibodies was determined by immunoblot (dot blot), as previously described [5, 6]. Briefly, Influenza virus vaccine Fluzone (5ul) $(90 \mathrm{ug} / \mathrm{mL}$ protein conc.) was pipetted onto nitrocellulose membrane strips (BIO-RAD Laboratories, Hercules, CA) and let dry. Nitrocellulose membrane was then soaked in a $5 \%$ milk powder (Immunetics Inc., Boston, MA) solution (Tween $20(0.05 \%$ Tween20 (Sigma) in tris buffered saline (20mM Tris-HCL (Sigma), $150 \mathrm{mM} \mathrm{NaCl}$, pH7.5 (Sigma).

\section{Detection of IgE anti Influenza}

Nitrocellulose membranes were then incubated with serum samples $(100 \mathrm{ul})$ (diluted in $2 \mathrm{ml}$ TBS-Tween 20) for $1 \mathrm{hr}$ at room temperature, after which goat IgG fraction to human IgE (MP Biomedicals, Solon, $\mathrm{OH}$ ), diluted 1:20-40 in TBS-Tween 20 and 
$1 \%$ milk in TBS-Tween $20(1 \mathrm{ml})$, was added to membranes, and incubated overnight on a shaker at room temperature.

\section{Detection of anti Influenza IgG}

IgG Fraction goat anti human IgG (heavy and light chains specific) (ICN/Cappell, West Chester, PA), diluted 1:100 in TBS-Tween 20 and 1\% milk in TBS-Tween $20(1 \mathrm{ml})$ was added to membranes and incubated for one hour on a shaker at room temperature. The membranes were then washed three times with TBS-Tween 20.

For detection and development of both IgG and IgE isotypes: nitrocellulose membranes were then incubated with rabbit anti-goat peroxidase labeled antibody (whole molecule) (Cappel, West Chester, PA), diluted 1:2000 in TBS-Tween 20 and 1\% Milk for 1 hour on a shaker, washed 3 times with TBS-Tween 20 , and then developed in TMB substrate solution (2 $\mathrm{ml}$ ). The membranes were then removed from the TMB substrate solution, at which time they were read dried, and scanned (Gel Doc 2000 System with specific The Discovery Series: Quantity One software BioRad, Hercules, CA).

\section{Cytokine determination}

Serum cytokines [Interleukin-2 (IL-2), Interferon gamma (IFN- $\gamma)$, Interleukin-4 (IL-4), Interluekin-10 (IL-10)] were determined by sandwich ELISA (Biosource, Camarillo, CA) according to the manufacturer's protocol.

\section{Statistical Analysis}

Cytokine determinations from vaccinated and non vaccinated subjects were compared on each variable. Significance between variables was determined using student's t-tests. A $p$ value of $<0.05$ was considered statistically significant for all comparisons.
The degree of association between these measures was assessed using Pearson's correlations. Statistical analyses were performed using SPSS for Windows, version 10.0 software (SPSS Inc., Chicago, IL).

\section{RESULTS.}

\section{Characteristics of Study Subjects}

Serum IgE levels and IgE and IgG anti-Influenza virus antibodies were studied in children $(\mathrm{N}=3)(\mathrm{m} / \mathrm{f}$ 14-16 y/o) and adults ( $\mathrm{N}=3)(\mathrm{m} / \mathrm{f}, 41-49 \mathrm{y} / \mathrm{o})$ approaching two years post vaccination, as well as in non infected, non-vaccinated children $(\mathrm{N}=2)(\mathrm{m} / 1$ y/o) (Table 1).

\section{Total IgE}

Total serum IgE levels were both normal and elevated in adults and children vaccinated with Influenza virus. Children with no history of either Influenza virus infection or vaccination had serum $\operatorname{IgE}$ levels which were low (Table 1).

\section{Anti-Influenza Abs}

IgG. Serum obtained from subjects who were vaccinated had positive dot blots for IgG anti-Influenza virus antibodies (Data not shown). In contrast, serum from non-infected, non-vaccinated (control) subjects did not contain IgG anti-VZV antibodies.

IgE. Serum obtained from 5 out of 6 vaccinated subjects $(83 \%)$ had positive dot blots for IgE anti-Influenza virus antibodies; they had either elevated or normal levels of serum IgE (Table 1) (Fig 1, lanes 1, 2). In contrast, serum from non-infected, non vaccinated subjects did not contain IgE anti-Influenza virus antibodies (Fig 1, lane 3); they had low levels of serum IgE.

TABLE I. CHARACTERISTICS OF STUDY SUBJECTS AND SERUM IgE LEVELS

\begin{tabular}{|c|c|c|c|c|c|}
\hline Patient & Sex/Age (years) & $\begin{array}{l}\text { Form of Influenza virus inocula- } \\
\text { tion (Fall 2009) }\end{array}$ & $\begin{array}{l}\text { Serum IgE levels } \\
(\mathrm{IU} / \mathrm{ml})\end{array}$ & $\begin{array}{l}\operatorname{IgE} \text { anti- Influenza } \\
\text { virus (+/-)\# }\end{array}$ & $\begin{array}{l}\text { IgG anti-Influenza virus } \\
(+/-)^{\#}\end{array}$ \\
\hline 1 & $\mathrm{~F}(18)$ & Flumist ${ }^{\circledR 1}$ & $154^{*}$ & + & + \\
\hline 2 & $\mathrm{~F}(41)$ & Fluzone ${ }^{\circledR 2}$ & 15 & + & + \\
\hline 3 & M (44) & Fluzone & $232^{*}$ & + & + \\
\hline 4 & M (14) & Flumist & 34 & + & + \\
\hline 5 & M (16) & Flumist** & 132 & - & + \\
\hline 6 & $\mathrm{~F}(49)$ & Fluzone & 34 & + & + \\
\hline 7 & $\mathrm{M}(1)$ & None & 14 & - & - \\
\hline 8 & $\mathrm{M}(1)$ & None & 15 & - & - \\
\hline
\end{tabular}

Patients were inoculataed with either ${ }^{1}$ Flumist ${ }^{\circledR}$ (live attenuated Influenza Virus Vaccine),

${ }^{2}$ Fluzone $^{\circledR}$ (inactivated Influenza Virus Vaccine) or none. *Patient skin test (skin prick) positive for food or environmental allergens. Reference range for healthy adult or child serum: IgE: 20-100 IU/mL.*Was given Flumist in 2008.

\# Immunoblot (See Material and Methods). 


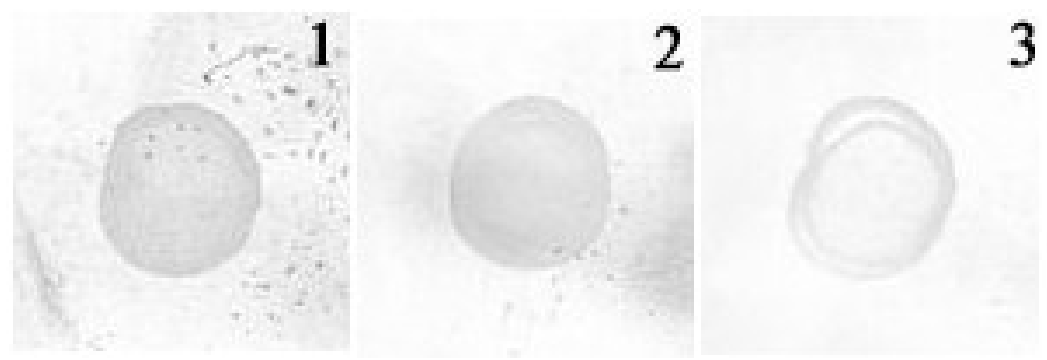

Figure I. Immunoblot analysis of IgE anti-influenza virus antibodies. Serum from subjects with past history of influenza virus vaccination or no infection was incubated with nitrocellulose strips containing influenza virus vaccine antigen (see Materials and Methods). Lane I: representative blot of subject vaccinated with influenza virus vaccine, who had elevated serum lgE levels (>100 IU/ml). Lane 2: representative blot of subject vaccinated with influenza virus vaccine who had low serum IgE levels (<100 IU/ml). Lane 3: control subject, no history of infection or vaccination.

\section{Cytokines in serum.}

Similar levels of IL-2, IFN- $\gamma$, IL-4, and IL-10 cytokines were detected in serum of vaccinated compared with non vaccinated subjects $(p>0.05)$, as well as between vaccinated adults compared with vaccinated children, compared with non vaccinated subjects ( $p>0.05)$ (data not shown).

\section{DISCUSSION}

The present studies are the first to describe the long-term persistence of IgE anti-Influenza virus antibodies in vaccinated children and adults, with normal and elevated levels of serum IgE, approaching two years post vaccination.

Influenza viruses are respiratory pathogens which belong to the Orthomyxoviridae family [20], and are a group of negative-stranded, segmented RNA viruses [20]. Three types of influenza virus (A, B, $C)$ have been reported which are categorized by their antigenic differences in the nucleoprotein and matrix protein [21]. Influenza A and B viruses commonly cause disease in humans [21]. The Influenza A virus has surface antigens, but diverse subtype-specific, haemagglutinin (HA) and neuraminidase (NA); antibodies to these viral antigens mediate immunity to infection [21]. When an influenza virus infection is first experienced, an IgM response is elicited to both type and subtype-specific antigens of influenza virus [22]; subsequent infections or vaccinations later in life to the type-specific antigens would be restricted to IgG responses [22].

Influenza virus causes annual epidemics, which generally occur in the winter months in the Northern hemisphere [21], and is spread from person to person by either direct contact with a virus infected individual, or by virus droplets from sneezing or coughing
[21]. An uncomplicated case of influenza will resolve within 1-2 weeks; however, in patients with other underlying medical conditions, infection with influenza may result in hospitalization and death [21].It has been reported that influenza has been responsible for high numbers of morbidity and mortality in the United States [23]. All age groups can be infected with Influenza virus, but children have the highest infection rates [24]. In the United States, vaccination is recommended for people with increased rate of medical conditions (50-64 y/o), and for children 6 months and older [21, 25]. In some countries, vaccination is recommended for health care workers, and caregivers in nursing homes and assisted living facilities [21].

It is well known that both humoral (mucosal and serum antibody responses), as well as cellular immune responses play a role in resistance to influenza infection [26-29]. sIgA, as well as IgM are the neutralizing antibodies in the mucosa that prevent virus entry and inhibit virus replication [30]. During primary infection, IgG, IgA and IgM- specific to HA have been detected in nasal washings by enzyme-linked immunosorbent assay, although IgA and IgM were more frequently detected than IgG [30]; IgE-specific to HA was not studied. Natural wild type Influenza virus infection can stimulate a local IgA response, which can last 3-5 months, as well as influenza-specific IgA-committed memory cells [30]. Levels of neutralizing antibodies induced by live virus vaccine correlate with resistance to infection after challenge with wild-type virus [28]. Previous studies by others reported that during primary infection, IgG, IgA, and IgM can be detected within 10-14 days [30]. Two weeks post infection, levels of IgA and IgM peak, and then begin to decline, whereas four to six weeks post infection, levels of IgG peak [30]. In the primary response IgG and IgM are dominant, and after second- 
ary infection, $\operatorname{IgG}$ and $\operatorname{IgA}$ are the predominant immunoglobulin isotypes detected in serum $[21,30]$.

It has been reported that in vaccinated individuals, 2-6 days post vaccination, serum antibody responses to trivalent (inactivated) influenza vaccine were detected, peaked 2-3 weeks post vaccination, and then was two-fold lower 6 moths post vaccination [31]; influenza specific IgG1 antibodies were the dominant antibody detected, as well as lower levels of $\operatorname{IgM}$ and IgA [31]; IgE antibodies were not studied. It should be mentioned that in the United States, mucosal vaccines for Influenza are now available for children, and target the mucosa and lymphoid tissue, which are areas where early infection occurs [32]. In other investigations, it has been shown that influenza virus-specific antibodies in saliva consist of SIgA1, which is first detected 5-7 days after vaccination, and the elevated antibody response lasts for 3-5 days [19, 31]. However, an increase of H1N1 and B strains influenza virus antibodies has been found in oral fluid 7 days post vaccination [18]. Levels of influenza virus-specific ASCs in blood is low before vaccination, compared with levels in tonsils and nasal mucosa [18]; after vaccination, this level increased nearly $4 \log _{10}$ [18]. Live, attenuated influenza vaccines induce both mucosal and systemic responses [21]. The cold-adapted (CA) live, attenuated vaccines are administered intranasally in children and provide protective immunity [21]. After CA vaccination, serum antibody responses and/or virus shedding has been noted in most recipients [21].

In the present study, vaccinated adult (live attenuated vaccine) and pediatric (nasal vaccine) patients (2-20 months post vaccination), with both normal and elevated serum IgE levels, had specific IgG and IgE anti-influenza antibodies, detected by immunoblot. Of notable interest under study, is the long-term persistence of these antibodies (approaching two years post vaccination). Although prior literature suggests that Influenza virus specific IgG antibodies wane 6 months post vaccination [31], we were able to detect both IgG and IgE specific Influenza virus antibodies up to two years post vaccination. It is conceivable that the detection of IgG and IgE reported here (dot blot technology) affords a greater level of sensitivity than previous reports which employ ELISA based approaches. In this manner our data are consistent with the detection of other reports with respect to immunoglobulin anti-influenza presence. However, in our studies, the levels of Ig anti-influenza antibodies over time were not determined.

Given the findings of this study, the presence and persistence of IgG and IgE anti-influenza antibodies in the serum from those with normal and ele- vated levels of $\operatorname{IgE}$ are understandable. Our findings appear to be of importance and relevant because previously described studies from our laboratory [33] have shown the presence of IgE anti-cancer antibodies present in patients with both normal and elevated IgE levels which were able to mediate antibody dependent cell mediated cytotoxicity against cancer cells in vitro. These responses were not correlated with total serum IgE levels. We therefore speculate that it is not the total IgE levels that are important but rather the fraction of IgE anti-influenza antibodies as a percentage of the total IgE pool that are responsible for mediating any effects. Our discovery also suggests that the IgE molecule has evolved to serve various beneficial functions, including anti-viral. However, at present, it is unclear how IgE promotes its activity in these viruses.

Although IgE anti-viral responses are demonstrated, the limitations of this study include small sample size, and the lack of racial disparity. All the subjects were Caucasian and in good health. It could be that the immunoglobulin anti-viral responses may differ in vaccinated subjects of African American or Hispanic descent as has been shown in other vaccine trials (34). Additional studies towards understanding immunoglobulin anti-viral responses in subjects and patients with co-morbidities or immunocompromise are warranted.

The results presented here suggest that $\operatorname{IgE}$ is associated with anti-influenza immunity and their memory responses. Further studies are necessary to elucidate the role of immunoglobulins in influenza infection and to determine possible functional roles of $\operatorname{IgE}$ in this disease and its relationship to viral pathophysiology.

\section{Conflict of Interest}

The authors have declared that no conflict of interest exists.

\section{References}

1. Bluth $\mathrm{MH}$, Norowitz KB, Chice $\mathrm{S}$, Shah VN, Nowakowski M, Josephson AS, Durkin HG, Smith-Norowitz TA. Detection of IgE anti-parvovirus B19 and increased CD23+ B cells in parvovirus B19 infection: relation to Th2 Cytokines. Clin. Immunol 2003; 108:152-158.

2. Secord EA, Kleiner GI, Auci DL, et al. IgE against HIV proteins in clinically healthy childen with HIV disease. J Allergy Clin Immunol 1996; 98: 979-84.

3. Pellegrino MG, Bluth MH, Smith-Norowitz TA, et al. HIV-1 Specific IgE in serum of long term surviving children inhibits HIV-1 production in vitro. AIDS Res. Hum. Retroviruses 2002; 18: 363-72.

4. Lev Tov H, Josekutty J, Kohlhoff S., Norowitz KB, Silverberg JI, Chice S, Nowakowski M, Durkin HG, Bluth MH, Smith-Norowitz TA. IgE anti-varicella virus (VZV) and other 
immune responses before, during, and after shingles. J Allergy Clin Immunol. 2008; 121: S207.

5. Smith-Norowitz TA, J Josekutty, H Lev-Tov, S Kohlhoff, KB Norowitz, JI Silverberg, S Chice, HG Durkin, MH Bluth. IgE anti-Varicella Zoster virus and other immune responses before, during, and after shingles. Ann Clin Lab Sci. 2009; 39 (1): 43-50.

6. Smith-Norowitz TA, Josekutty J, Lev-Tov H, Norowitz KB, Kohlhoff SA, Silverberg JI, Nowakowski M, Durkin HG, Bluth $\mathrm{MH}$. Long term persistence of IgE anti-Varicella Zoster Virus in pediatric and adult serum post chicken pox infection and after vaccination with Varicella Virus vaccine. Int J Biomed Sci. 2009;: 100-105.

7. Bluth MH, Robin J, Ruditsky M, Norowitz KB, Chice S, Pytlak E, Nowakowski M, Durkin HG, Smith-Norowitz TA. IgE anti-borrelia burgdorferi components (p18, p31, p34, p41, p45, p60) and increased blood CD8+CD60+ T cells in children with lyme diseaese. Scan J Immunol 2007; 65: 376-382.

8. Welliver RC, Wong DT, Sun M, Middleton JrE, Vaughan RS, Ogra PL. The development of respiratory syncytial virus-specific $\operatorname{IgE}$ and the release of histamine in nasopharyngeal secretions after infection. New England J. of Med 1981; 305: 841-846.

9. Russi JC, Delfraro A, Borthagaray MD, Velazques B, Garcia-Barreno B, Hortal M. Evaluation of immunoglobulin E-specific antibodies and viral antigens in nasopharyngeal secretions of children with respiratory syncytial virus infection. J. Clin. Microbiol 1993; 31: 819-823.

10. Welliver RC, Wong DT, Middleton JrE, Sun M, McCarthy N, Ogra PL. Role of parainfluenza virus-specific IgE in pathogenesis of croup and wheezing subsequent to infection. J. Pediatrics 1982; 101: 889-896.

11. Beaudouin E, Kanny G, Guerin B,Guerin L, Plenat F, Moneret-Vautrin DA. Unusual manifestations of hypersensitivity after a tick bite: report of two cases. Ann Allergy Asthma Immunol 1997; 79: 43-46.

12. Alexeyev OA, Ahlm C, Billheden J, Settergren B, Wadell G, Juto $P$. Elevated levels of total and Puumala virus-specific immunoglobulin E in the Scandinavian type of hemorrhagic fever with renal syndrome. Clin. Diag. Lab. Immunol 1994; 1: 269-272.

13. Kennedy CR, Bird D, Chrzanowska K, Stephens S, Webster AD. The pathogenesis of virus-associated encephalopathies: a prospective study of immunological mechanisms. Clin. Immunol. Immunopathol 1987; 42: 218-228.

14. Odeon AC, Gershwin LJ, Osburn BI. IgE responses to bluetongue virus (BTV) serotype 11 after immunization with inactivated BTV and challenge infection. Comp Immunol Imcrobiol Infect Dis. 1999; 22: 145-163.

15. Grunewald SM, Hahn C, Wohlleben G, Teufel M, Major T, Moll $\mathrm{H}$, Brocker E-B, Erb KJ. Infection with Influenza A virus leads to flu antigen-induced cutaneous anaphylaxis in mice. J Invest Dermatol 2002; 118: 645-651.

16. Davidsson A, Eriksson JC, Rudblad S, Brokstad KA. Influenza specific serum IgE is present in non-allergic subjects. Scan J Immunol 2005; 62(6): 560-561.

17. Dobber R, Tielemans $M$, Nagelkerken $L$. The in vivo effects of neutralizing antibodies against IFN-gamma, IL-4, or IL-10 on the humoral immune response in young and aged mice. Cell Immunol 1995; 160: 185-192.

18. Brokstad KA, Eriksson JC, Cox RJ, Tynning T, Olofsson J, Jonsson R, Davidsson A. Parenteral vaccination against influenza does not induce a local antigen-specific immune response in the nasal mucosa. J Infect Dis 2002; 185(7): 878-884.

19. Brokstad KA, Cox RJ, Oxford JS, Haaheim LR. IgA, IgA subclasses, and secretory component levels in oral fluid collected from subjects after parenteral influenza vaccination. J Infect Dis 1995; 171: 1072-1074.
20. Wright PF, Webster RG. Orthomyxoviruses. In: Knipe DM, Howley PM, Griffin DE, Lamb RA, Martin MA, Roizman B, Straus SE, eds. Fields Virology, 4th edn. Philadelphia, PA: Lippincott Williams \& Wilkins, 2001: 1533-79.

21. Cox RJ, Brokstad KA, Ogra P. Influenza virus: immunity and vaccination strategies. Comparison of the immune response to inactivated and live, attenuated influenza vaccines. Scan J Immunol 2004; 59: 1-15.

22. Gonchoroff NJ, Kendal AP, Phillips DJ, Reimer CB. Immunoglobulin $M$ and $G$ antibody response to type- and subtype-specific antigens after primary and secondary exposures of mice to Influenza A viruses. Infect and Immunity 1983;: 510-517.

23. Lui K-J, Kendal AP. Impact of influenza epidemics on mortality in the United States from October 1972 to May 1985. Am J Public Health 1987; 77: 712-716.

24. Glezan WP, Taber LH, Frank AL, Gruber WC, Piedra PA. Influenza virus infection in infants. Pediatr Infect Dis J 1997; 16: 1065-1068.

25. [Internet] CDC. 2010-11 Influenza Prevention \& Control Recommendations: Primary Changes and Updates in the 2010 ACIP Recommendations. http://www.cdc.gov/flu/ professionals/acip/primarychanges.htm

26. Clements ML, O'Donnell S, Levine MM, Chanock RM, Murphy BR. Dose response of A/Alaska/6/77 (H3N2) cold-adapted reassortant vaccine virus in adult volunteers: role of local antibody in resistance to infection with vaccine virus. Infect Immun 1983; 40: 1044-1051.

27. Clements ML, Betts RF, Tierney EI, Murphy BR. Serum and nasal wash antibodies associated with resistance to experimental challenge with influenza A wild-type virus. J Clin Microbiol 1986; 24: 157-160.

28. Clements ML, Murphy BR. Development and persistence of local and systemic antibody responses in adults given live attenuated or inactivated influenza A virus vaccine. J Clin Microbiol 1986; 23: 66-72.

29. Yewdell JW, Hackett CJ. The specificity and function of $\mathrm{T}$ lymphocytes and antibody dependent complement-mediated cytotoxicity induced by administration of influenza vaccine. Infect Immun 1980; 30: 362-369.

30. Murphy BR, Clements ML. The systemic and mucosal immune response of humans to Influenza A virus. In: Mestecky J, McGhee JR, eds. Current Topics in Microbiology and Immunology. New York, NY: Springer Verlag, 1989, 107-116.

31. Cox RJ, Brokstad KA, Zuckerman MA, Wood JM, Haaheim LR, Oxford JS. An early humoral immune response in peripheral blood following parenteral inactivated influenza vaccination. Vaccine 1994; 12: 993-999.

32. Ogra PL, Faden H, Welliver RC. Vaccination strategies for mucosal immune responses. Clin Microbiol Rev 2001; 14: 430-445.

33. Fu S, Pierre J, Smith-Norowitz TA, Hagler M, Bowne W, Pincus MR, Mueller CM, Zenilman ME, Bluth MH. IgE antibodies from pancreatic cancer patients mediate antibody-dependent cell meditate cytotoxicity (ADCC) against pancreatic cancer cells. Clin and Exp Immunol 2008;153:401-409

34. TP Monath, R Nichols, WT Archambault, L Moore, R Marchesani, J Tian, RE Shope, N Thomas, R Schrader, D Furby, and P Bedford. Comparative safety and immunogenicity of two yellow fever 17D vaccines (ARILVAX and YF-VAX) in a phase III multicenter, double-blind clinical trial. Am. J. Trop. Med. Hyg. 2002;66:533-541 